\title{
Experience of using beta-D-glucan assays in the intensive care unit
}

\author{
A. Dagens ${ }^{1,2^{*}}$, N. Mughal ${ }^{1,3,4}$, A. Sisson ${ }^{1}$ and L. S. P. Moore ${ }^{1,3,4}$ \\ See related research by Giacobbe et al., https://ccforum.biomedcentral.com/articles/10.1186/s13054-017-1763-5
}

We read with interest the article by Giacobbe et al. [1] assessing the combined performance of serum $(1,3)-\beta-D$ glucan (BDG) and procalcitonin (PCT) for the differential diagnosis of candidaemia and bacteraemia in the intensive care setting.

It is our experience that some intensivists lack familiarity with the role of BDG assays and that it is often not a readily available test. To understand how BDG assays were being used in our department we undertook a retrospective observational study. Ours is a central London teaching hospital with a 13-bed mixed medical/surgical ICU. All BDG assays sent from the ICU to a national reference laboratory over a 3-year period (September 2014 to March 2017) were extracted, and clinical and laboratory parameters collated to assess the impact on patient outcomes.

Thirty assays were identified among 704 patients, with a mean patient age of 58 (range 21-86). Most (11/30) of these patients had been admitted to ICU for respiratory disease. A clinical candida score was calculated for each patient (mean 3, mode 4), suggesting a high pre-test probability for invasive fungal disease (IFD).

The average turnaround time was 5 days (range 310 days), with $6 / 30$ positive. Twenty-six patients had been started on antifungal medication empirically whilst awaiting assay results. On return of negative assay results five patients had their antifungals stopped within $24 \mathrm{~h}$ of the result; 120 patient-days of antifungal treatment were given whilst awaiting negative assay results.

Serological BDG assays are a potentially useful tool in the diagnosis of IFD and can facilitate antifungal stewardship. However, complicating factors limit their use, particularly where outsourcing to an external laboratory prolongs turnaround times. Antifungal agents are expensive. Based upon NHS list prices for our formulary echinocandin, this study identified $£ 49,920$ spent unnecessarily on antifungal agents.

Mortality was high in our cohort (50\%), perhaps reflecting the fact that IFD is often only considered in patients who are not improving in ICU. It was noticeable how few assays were sent during the 3-year period, possibly reflecting a lack of awareness of BDG amongst intensivists.

\section{Authors' contributions}

AD wrote the manuscript and is the corresponding author. LPSM, AS and NM supervised the project and contributed to the audit design. All authors read and approved the final manuscript.

Ethics approval and consent to participate Not applicable.

\section{Competing interests}

LSPM consulted for Dairy Crest (2017), DNA electronics (2014) and bioMerieux (2014) and has received educational grants from Eumedica and research grants from Leo Pharma and NIHR. Other authors have nothing to declare.

\section{Publisher's Note}

Springer Nature remains neutral with regard to jurisdictional claims in published maps and institutional affiliations.

\section{Author details}

${ }^{1}$ Chelsea and Westminster Hospital, 369 Fulham Rd, Chelsea, London SW10 9NH, UK. ${ }^{2}$ Royal Air Force, London, UK. ${ }^{3} \mathrm{NWL}$ Pathology at Imperial College Healthcare NHS Trust, Fulham Palace Road, London W6 8RF, UK. ${ }^{4}$ Imperial

College London, Exhibition Road, London, UK.

Received: 8 April 2018 Accepted: 17 April 2018

Published online: 12 May 2018

\section{Reference}

1. Giacobbe DR, Malgorzata M, Tumbarello M, Furfaro E, Spadaro M, Losito AR, Mesini A, De Pascale G, Marchese A, Bruzzone M, Pelosi P, Mussap M, Molin A, Antonelli M, Posteraro B, Sanguinetti M, Viscoli C, Del Bono V. Combined use of serum (1,3)- $\beta$ - $d$-glucan and procalcitonin for the early differential diagnosis between candidaemia and bacteraemia in intensive care units. Crit Care. 2017;21:176.

\footnotetext{
* Correspondence: drewdagens@doctors.org.uk

${ }^{1}$ Chelsea and Westminster Hospital, 369 Fulham Rd, Chelsea, London SW10 $9 \mathrm{NH}$, UK

${ }^{2}$ Royal Air Force, London, UK

Full list of author information is available at the end of the article
}

(c) The Author(s). 2018 Open Access This article is distributed under the terms of the Creative Commons Attribution 4.0 International License (http://creativecommons.org/licenses/by/4.0/), which permits unrestricted use, distribution, and reproduction in any medium, provided you give appropriate credit to the original author(s) and the source, provide a link to the Creative Commons license, and indicate if changes were made. The Creative Commons Public Domain Dedication waiver (http://creativecommons.org/publicdomain/zero/1.0/) applies to the data made available in this article, unless otherwise stated. 